Article

\title{
Tri-Functional Calcium-Deficient Calcium Titanate Coating on Titanium Metal by Chemical and Heat Treatment
}

\author{
Seiji Yamaguchi *, Phuc Thi Minh Le, Morihiro Ito ${ }^{\mathbb{D}}$, Seine A. Shintani and Hiroaki Takadama \\ Department of Biomedical Sciences, College of Life and Health Sciences, Chubu University, Aichi 487-8501, Japan \\ * Correspondence: sy-esi@isc.chubu.ac.jp; Tel.: +81-568-51-6420
}

Received: 6 August 2019; Accepted: 27 August 2019; Published: 3 September 2019

check for updates

\begin{abstract}
The main problem of orthopedic and dental titanium (Ti) implants has been poor bone-bonding to the metal. Various coatings to improve the bone-bonding, including the hydroxyapatite and titania, have been developed, and some of them have been to successfully applied clinical use. On the other hand, there are still challenges to provide antibacterial activity and promotion of bone growth on Ti. It was shown that a calcium-deficient calcium titanate coating on Ti and its alloys exhibits high bone-bonding owing to its apatite formation. In this study, Sr and Ag ions, known for their promotion of bone growth and antibacterial activity, were introduced into the calcium-deficient calcium titanate by a three-step aqueous solution treatment combined with heat. The treated metal formed apatite within 3 days in a simulated body fluid and exhibited antibacterial activity to Escherichia coli without showing any cytotoxicity in MC3T3-E1 preosteoblast cells. Furthermore, the metal slowly released $1.29 \mathrm{ppm}$ of $\mathrm{Sr}$ ions. The Ti with calcium-deficient calcium titanate doped with Sr and Ag will be useful for orthopedic and dental implants, since it should bond to bone because of its apatite formation, promote bone growth due to Sr ion release, and prevent infection owing to its antibacterial activity.
\end{abstract}

Keywords: antibacterial activity; bone growth; apatite formation; titanium; silver; strontium; calcium titanate; ion release; cytotoxicity; controlled release

\section{Introduction}

Titanium metal (Ti) and its alloy are widely used for orthopedic and dental implants since they fulfill certain clinical needs from the point of view of mechanical properties, durability, and biocompatibility. Osseointegration occurs when the surfaces of the metals were roughened at micrometer scale such as $0.5-2.0$, or 3.6-5.6 $\mu \mathrm{m}$ in calculated average roughness $R_{\mathrm{a}}$, and $43-50 \mu \mathrm{m}$ in maximum height $R_{\mathrm{z}}$ by plasma spraying, grid blasting and/or acid etching [1,2]. The nanometer-scale roughness produced by anodic oxidation also has been found to increase cell adhesion, proliferation and alkaline phosphatase activity $[3,4]$. Although these roughened Ti surfaces are able to directly contact with living bone, they still do not bond to it adequately. Mineralization process is a promising method to achieve strong and stable bone-bonding. It has been reported that bioactive glass/ceramics such as bioglass, hydroxyapatite, and glass ceramics A-W directly bonded to bone through the bone-like apatite layer formed on their surfaces [5].

Various types of surface coating of bioactive glass/ceramics by plasma spray, sputtering, sol-gel, and alternative soaking have been attempted [6-8]. Among them, a plasma spray coating of hydroxyapatite has been widely used to confer bone-bonding to total hip joint, dental implant, and so on. However, this does not form a stable bioactive surface layer, since the surfaces of the hydroxyapatite particles exposed to the plasma are partially melted, so the resultant calcium phosphate coating is liable to be decomposed in the living body in process of time [6]. 
Various types of surface modifications including alkali/acid solution and heat treatment, hydrothermal treatment, and ion implantation have been developed to confer apatite-forming capability on the metals so that the activated metals form bone-like apatite spontaneously on their surfaces by using the calcium and phosphate present in body fluids, and thereby bond to bone through the apatite [9-12]. Among the variety of the modification techniques, the alkali/acid solution and heat treatment has the needed characteristics for producing a uniform activated surface layer, even on the inner wall of a porous body, without requiring any especial apparatus $[13,14]$. It has been demonstrated that a bioactive sodium titanate layer is produced on Ti when the metal is soaked in $5 \mathrm{M} \mathrm{NaOH}$ solution at $60{ }^{\circ} \mathrm{C}$ for $24 \mathrm{~h}$ and subsequently heat-treated at $600{ }^{\circ} \mathrm{C}$ for $1 \mathrm{~h}[15,16]$. The surface of treated metal forms a bone-like apatite spontaneously in the living body and bonds bone through this layer [16]. Total artificial hip joints (THAs) with the bioactive sodium titanate layer on their porous Ti layer have been under clinical use since 2007. A recent ten-year follow-up revealed the beneficial effects of the NaOH-heat-treated THAs to be a high survival rate (98\%), no radiographic signs of loosening, and both early and stable bone-bonding [17]. However, two joints were retrieved owing to deep infection and periprosthetic femoral fracture, since the $\mathrm{NaOH}$-heat-treated THAs neither promoted bone growth nor prevented infection [17]. Subsequently, the $\mathrm{NaOH}$-heat treatment was modified to $\mathrm{NaOH}-\mathrm{CaCl}_{2}$-heat-water treatment to produce a calcium-deficient calcium titanate layer on $\mathrm{Ti}$ and $\mathrm{Ti}$ alloys, which resulted in more stable apatite formation and bone-bonding [18-20]. On the other hand, there are still the challenges of providing antibacterial activity and promoting bone growth on Ti. It has been reported that typically $1 \%-2 \%$ of patients with total hip arthroplasties suffer deep infections [21]. Dental peri-implant disease and infection have become a main focus of oral implantology [22].

Strontium (Sr) and silver (Ag) ion are candidates for the promotion of new bone formation and prevention of infection since the former exerts a therapeutic effect on osteoporosis bone due to increased new bone formation and deceased bone resorption, while the later prevents infection because of its strong effect against a broad range of microorganisms [23-26]. Pre-clinical study reports have shown that the Sr ions released from dosed strontium ranelate improve mineral density at various skeletal sites such as the total hip and lumbar spine, resulting in the improvement of osteoporosis [23,24]. The mechanism of the antimicrobial action of $\mathrm{Ag}$ ions is understood as resulting from an interaction with the thiol (sulfhydryl) groups in enzymes and proteins [25], and is effective even in the living body [26]. Studies have reported the separate incorporation of $\mathrm{Sr}$ or Ag into the surface of $\mathrm{Ti}$ and $\mathrm{Ti}$ alloys [27-30], but there are few reports of these ions being incorporated simultaneously. There are even reported attempts to incorporate these ions into the Ti surface in an effort to confer a capacity for apatite formation. It was reported that Ag-doped calcium phosphate coatings was produced on $\mathrm{Ti}$ by a combination of anodic oxidation, electrophoretic deposition, and magnetron-sputtering [31,32]. Although the coated metal exhibited strong antibacterial activity against Escherichia coli (E. coli), it a little decreased cell viability [32]. A novel method is desired to confer Ti the capabilities of excellent antibacterial activity without any decrease in cell viability, direct bone-bonding, and promotion of new bone formation at the same time.

In this study, $\mathrm{Sr}$ and $\mathrm{Ag}$ ions were introduced into the calcium-deficient calcium titanate produced on Ti under controlled conditions so that the treated Ti slowly released Sr and Ag ions in order to exhibit the functions of promoting new bone formation while preventing infection without decreasing apatite formation. The potential of the treated metal for clinical applications is discussed in terms of $\mathrm{Sr}$ and Ag ion release, antibacterial activity, cytocompatibility, and apatite formation.

\section{Materials and Methods}

\subsection{Surface Treatment}

Commercially pure Ti sections (Ti > 99.5\%; Nilaco Co., Tokyo, Japan) $10 \mathrm{~mm} \times 10 \mathrm{~mm} \times 1 \mathrm{~mm}$ in size was grinded with $\# 400$ diamond plates and then cleaned in an ultrasonic bath by using acetone, 2-propanol and ultrapure water for $30 \mathrm{~min}$, and dried at $40^{\circ} \mathrm{C}$ overnight. They were immersed in 
$5 \mathrm{M} \mathrm{NaOH}$ (Reagent grade; Kanto Chemical Co., Inc., Tokyo, Japan) solution at $60^{\circ} \mathrm{C}$ with shaking at $120 \mathrm{strokes} / \mathrm{min}$ for a period of $24 \mathrm{~h}$ followed by gentle rinse under ultrapure water flow for $30 \mathrm{~s}$. The treated metals were soaked in a mixed solution consist of $50 \mathrm{mM} \mathrm{CaCl}_{2}$ (Reagent grade; Kanto Chemical Co., Inc., Tokyo, Japan) and $50 \mathrm{mM} \mathrm{SrCl} 2$ (Reagent grade; Kanto Chemical Co., Inc., Tokyo, Japan) at $40^{\circ} \mathrm{C}$, shaken at 120 strokes/min for $24 \mathrm{~h}$, then washed and dried in a similar manner (designated as “Ca $\left.+\mathrm{Sr}^{\prime \prime}\right)$. They were subsequently heated at $600^{\circ} \mathrm{C}$ with programming rate of $5{ }^{\circ} \mathrm{C} / \mathrm{min}$ and holding time of $1 \mathrm{~h}$, then naturally cooled in an electric furnace. After the heat treatment, they were immersed in a mixed solution of $1 \mathrm{M} \mathrm{Sr}\left(\mathrm{NO}_{3}\right)_{2}$ (Reagent grade; Kanto Chemical Co., Inc., Tokyo, Japan) and $X$ $\mathrm{mM} \mathrm{AgNO}_{3}$ (Reagent grade; Kanto Chemical Co., Inc., Tokyo, Japan) with an adjusted $\mathrm{pH}$ from 3 to 8 by adding $\mathrm{HNO}_{3}$ or $\mathrm{NH}_{3}(\mathrm{aq})$ at $80^{\circ} \mathrm{C}$, where $\mathrm{X}$ is a range from 1 to $100 \mathrm{mM}$ and designated as " $\mathrm{Sr}+\mathrm{X}$ $\mathrm{mM} \mathrm{Ag}$, shaken, washed, and dried in the in a similar manner. The nominal and measured $\mathrm{pH}$ of the $1 \mathrm{M} \mathrm{Sr}\left(\mathrm{NO}_{3}\right)_{2}+1 \mathrm{mM} \mathrm{AgNO} 3$ are summarized in Table 1. Some of the Ti samples subjected to the same $\mathrm{NaOH}-\mathrm{Ca}+\mathrm{Sr}-\mathrm{heat}$ treatment were subsequently soaked in $1 \mathrm{M} \mathrm{SrCl}_{2}$ solution without $\mathrm{Ag}$ for comparison.

Table 1. Measured $\mathrm{pH}$ of $1 \mathrm{M} \mathrm{SrNO}_{3}+1 \mathrm{mM} \mathrm{AgNO}$ solution corresponding to nominal $\mathrm{pH}$.

\begin{tabular}{ccc}
\hline Nominal $\mathbf{p H}$ & Measured $\mathbf{p H}$ & Additive \\
\hline $\mathrm{pH}=3$ & 3.06 & $\mathrm{HNO}_{3}$ \\
$\mathrm{pH}=4$ & 3.90 & $\mathrm{HNO}_{3}$ \\
$\mathrm{pH}=5$ & 4.80 & $\mathrm{No} \mathrm{additives}$ \\
$\mathrm{pH}=6$ & 6.01 & $\mathrm{NH}_{3}(\mathrm{aq})$ \\
$\mathrm{pH}=7$ & 7.16 & $\mathrm{NH}_{3}(\mathrm{aq})$ \\
$\mathrm{pH}=8$ & 7.83 & $\mathrm{NH}_{3}(\mathrm{aq})$ \\
\hline
\end{tabular}

\subsection{Surface Analysis}

\subsubsection{Scanning Electron Microscopy and Energy Dispersive X-ray Analysis}

The samples treated with the aqueous solution and heat were examined by field emission scanning electron microscopy (FE-SEM: S-4300, Hitachi Co., Tokyo, Japan) equipped with an energy dispersive X-ray spectrometer (EDX: EMAX-7000, Horiba Ltd., Kyoto, Japan). In FE-SEM observation, the samples were subjected to a thin-film coating of $\mathrm{Pt}-\mathrm{Pd}$, and $15 \mathrm{kV}$ accelerate voltage was selected. In EDX anlaysis, the elements of $\mathrm{Ca}, \mathrm{Ag}, \mathrm{O}$, and Ti were quantified using $9 \mathrm{kV}$. The measurement was repeated on five different points, and their averaged value was used.

\subsubsection{Thin-Film X-ray Diffraction and Fourier Transform Confocal Laser Raman Spectrometry}

The surface structure of the samples subjected to the aqueous solution and heat treatment were analyzed by a thin-film X-ray diffractometer (TF-XRD: model RNT-2500, Rigaku Co., Tokyo, Japan) and Fourier transform confocal laser Raman spectrometer (FT-Raman: LabRAM HR800, Horiba Jobin Yvon, Longjumeau, France). In TF-XRD, the measurement was conducted at a power of $50 \mathrm{kV}$ and $200 \mathrm{~mA}$. A CuK was used as X-ray source and the incident beam angle was set to $1^{\circ}$ against the sample surface. In FT-Raman, measurement was conducted with $514.5 \mathrm{~nm}$ Ar laser at $16 \mathrm{~mW}$ of power excitation.

\subsubsection{Scratch Resistance}

The scratch resistance of the surface layer to the metal substrate was examined by a thin-film scratch tester (CSR-2000, Rhesca Co., Ltd., Tokyo, Japan) according to JIS R-3255. A stylus with diameter of $5 \mu \mathrm{m}$ and spring constant of $200 \mathrm{~g} / \mathrm{mm}$ was pressed into the treated metal surface under the conditions of scratch speed of $10 \mu \mathrm{m} / \mathrm{s}$, loading rates of $100 \mathrm{mN} / \mathrm{min}$, and amplitude of $100 \mu \mathrm{m}$. Five measurements were performed on each sample, and their averaged values were used for analysis. 


\subsubsection{X-ray Photoelectron Spectroscopy}

The allocation of elements such as $\mathrm{Ag}, \mathrm{Sr}, \mathrm{Ca}, \mathrm{Ti}, \mathrm{O}$ and $\mathrm{C}$ on the treated samples was analyzed using X-ray photoelectron spectroscopy (XPS, PHI 5000 Versaprobe II, ULVAC-PHI, Inc., Kanagawa, Japan) with Ar sputtering (spattering rate was $4 \mathrm{~nm} / \mathrm{min}$ as $\mathrm{SiO}_{2}$ conversion). In the analysis, the X-ray source of an Al-K radiation line was used with the take-off angle at $45^{\circ}$.

The obtained spectra were calibrated by $284.8 \mathrm{eV}$ in binding energy of $\mathrm{C} 1 \mathrm{~s}$ peak that is of the surfactant $\mathrm{CH}_{2}$ groups on the substrate.

\subsection{Ion Release}

The treated samples were immersed in $2 \mathrm{~mL}$ of fetal bovine serum (FBS) (Gibco, Thermo Fisher Scientific, Waltham, MA, USA) with gently shaken at a speed of 50 strokes/min at $36.5^{\circ} \mathrm{C}$. After predetermined periods up to 14 days, the $\mathrm{Sr}^{2+}$ and $\mathrm{Ag}^{+}$ion concentrations in the FBS were determined by inductively coupled plasma emission spectroscopy (ICP, SPS3100, Seiko Instruments Inc., Chiba, Japan). The measurement was repeated 3 times for independently prepared samples, and their averaged values were calculated.

\subsection{Soaking in Simulated Body Fluid (SBF)}

After the aqueous solution and heat treatment the samples were immersed in $24 \mathrm{~mL}$ of acellular simulated body fluid (SBF) [33] that had been prepared according to ISO 23317. $\mathrm{NaCl}, \mathrm{NaHCO}_{3}, \mathrm{KCl}$, $\mathrm{K}_{2} \mathrm{HPO}_{4} \cdot 3 \mathrm{H}_{2} \mathrm{O}, \mathrm{MgCl}_{2} \cdot 6 \mathrm{H}_{2} \mathrm{O}, \mathrm{CaCl}_{2}$ and $\mathrm{Na}_{2} \mathrm{SO}_{4}$ were purchased from Nacalai Tesque Inc., Kyoto, Japan and all of them were reagent grade. They were dissolved in fresh ultrapure water in this order, and their $\mathrm{pH}$ was adjusted exactly to $7.40 \mathrm{using}$ tris(hydroxymethyl)aminomethane $\left(\mathrm{CH}_{2} \mathrm{OH}\right)_{3} \mathrm{CNH}_{2}$ and $1 \mathrm{M} \mathrm{HCl}$ at $36.5^{\circ} \mathrm{C}$. After immersion periods of 3 days, the samples were rinsed and dried. Apatite formation formed on the metal surface was examined using FE-SEM, TF-XRD, and EDX.

\subsection{Antibacterial Activity Test}

The antibacterial activity of the treated Ti samples was evaluated by the film contact method (ISO22196) [34]. An E. coli (IFO 3972) suspension of $100 \mu \mathrm{L}$ was inoculated on the treated Ti samples at $25 \mathrm{~mm} \times 25 \mathrm{~mm} \times 1 \mathrm{~mm}$ and then covered with a $20 \mathrm{~mm} \times 20 \mathrm{~mm}$ polypropylene film that had been sterilized with ethanol and dried for 7 days in a clean bench. They were placed in a $100 \mathrm{~mm}$ diameter petri dish with a sterilized plastic cap filled with sterilized pure water to prevent drying of the bacterial suspension, and then stored in an incubator under $95 \%$ relative humidity at $35^{\circ} \mathrm{C}$ for $24 \mathrm{~h}$. After incubation, each sample was washed with $10 \mathrm{~mL}$ of a soybean casein digest broth containing lecithin and polyoxyethylene sorbitan monooleate (SCDLP broth) to collect the bacteria. The recovered suspension was subjected to ten-fold serial dilutions, followed by placed in petri dishes containing standard plate count agar at $35^{\circ} \mathrm{C}$ for $48 \mathrm{~h}$. After incubation, the number of viable E. coli was calculated using the dilution factor and the number of colonies that was counted on the petri dish. Finally, the antibacterial activity value $(R)$ was calculated for each specimen as follows:

$$
R=\{\log (B / A)-\log (C / A)\}=\log (B / C)
$$

where $A$ and $B$ are the numbers of viable $E$. coli recovered from the untreated specimen immediately or $24 \mathrm{~h}$ incubation after inoculation. $C$ is the number of viable $E$. coli recovered from the treated specimen immediately after $24 \mathrm{~h}$ incubation.

\subsection{Cell Proliferation}

MC3T3-E1 cells (subclone 14, ATCC, Manassas, VA, USA) were seeded onto Ti disk specimens that were $18 \mathrm{~mm}$ in diameter in 12 -well plates at a density of $2 \times 10^{4}$ cells/well. They were cultured in $\alpha$-MEM (Gibco, Thermo Fisher Scientific, Waltham, MA, USA) with 10\% FBS and 1\% penicillin/streptomycin at 
$37^{\circ} \mathrm{C}$ in $5 \% \mathrm{CO}_{2}$ atmosphere. After 1 and 3 days, the cell count reagent SF (Nacalai tesque, Kyoto, Japan) was added to the medium and stored in the incubator for $2 \mathrm{~h}$. After the incubation, $100 \mu \mathrm{L}$ of the medium was taken to a 96-well plate. The absorbance at $450 \mathrm{~nm}$ that is attributed to formazan product derived from living cells was quantified by a Microplate reader (iMark ${ }^{\mathrm{TM}}$, Bio-Rad, Hercules, CA, USA). Four disk specimens were prepared for each sample type in this measurement.

\subsection{Statistical Analysis}

The obtained data in Section 2.6 was statistically analyzed by out using $R$ language with these libraries (mvtnorm, survival, MASS, TH. data, multcomp, abind). The sample group data were initially tested for normality (Kolomogorov-Smirnov test) and homoscedasticity of variance (Bartlett's test). One-way analysis of variance (ANOVA) was adopted in the groups that satisfy those conditions to find any significant differences in the measured variables between control and treatment groups. When a difference was detected ( $p$-value $<0.05)$, Tukey's multiple comparison test was performed to identify which treatment groups were significantly different. In this case, the ANOVA was satisfied in all analyses.

\section{Results}

\subsection{Effect of the $p H$ of the Solution Used on Apatite Formation}

The chemical composition of the Ti surface after each aqueous solution and heat treatment was analyzed by EDX analysis. As shown in Table 2, 5.1\% Na was induced by the initial $\mathrm{NaOH}$ treatment, and then replaced with $2.2 \% \mathrm{Ca}$ and $1.3 \% \mathrm{Sr}$ by the subsequent $\mathrm{Ca}+\mathrm{Sr}$ treatment, which remained after the heat treatment. When the treated metal was immersed in $1 \mathrm{M} \mathrm{SrCl}_{2}$ solution, amount of $\mathrm{Sr}$ a little increased, probably due to the additional induce of $\mathrm{Sr}$ into the surface because of high concentration of $\mathrm{Sr}$ ions in the solution. When the treated Ti specimens were soaked in $1 \mathrm{M} \mathrm{Sr}\left(\mathrm{NO}_{3}\right)_{2}$ and $1 \mathrm{mM} \mathrm{AgNO} 3$ with a pH equal to or less than $4,0.2 \%$ of the Ag was introduced into the surface, while the Ca amount was slightly decreased. In contrast, no decrease in the Ca content was observed when the Ti specimens were soaked in a solution with a $\mathrm{pH}$ greater than 4 . The amount of Ag intoroduced into the Ti surface tended to decrease with an increase in the $\mathrm{pH}$ of the solution.

Table 2. The results of EDX analysis on the surface of Ti subjected to $\mathrm{Sr}+1 \mathrm{mM}$ Ag treatment with various $\mathrm{pH}$ following $\mathrm{NaOH}, \mathrm{Ca}+\mathrm{Sr}$ and heat treatment.

\begin{tabular}{|c|c|c|c|c|c|c|}
\hline \multirow{2}{*}{ Treatment } & \multicolumn{6}{|c|}{ Element/at.\% } \\
\hline & $\mathrm{O}$ & Ti & $\mathbf{N a}$ & $\mathrm{Ca}$ & $\mathrm{Sr}$ & Ag \\
\hline $\mathrm{NaOH}$ & 65.1 & 29.8 & 5.1 & 0 & 0 & 0 \\
\hline $\mathrm{NaOH}-\mathrm{Ca}+\mathrm{Sr}$ & 68.1 & 28.4 & 0 & 2.2 & 1.3 & 0 \\
\hline $\mathrm{NaOH}-\mathrm{Ca}+\mathrm{Sr}-$ heat & 68.9 & 27.6 & 0 & 2.3 & 1.3 & 0 \\
\hline $\mathrm{NaOH}-\mathrm{Ca}+$ Sr-heat-Sr $+1 \mathrm{mM} \mathrm{Ag}(\mathrm{pH}=3)$ & 66.8 & 29.8 & 0 & 1.8 & 1.4 & 0.2 \\
\hline $\mathrm{NaOH}-\mathrm{Ca}+$ Sr-heat-Sr $+1 \mathrm{mM} \mathrm{Ag}(\mathrm{pH}=4)$ & 65.8 & 30.5 & 0 & 1.9 & 1.6 & 0.2 \\
\hline $\mathrm{NaOH}-\mathrm{Ca}+$ Sr-heat-Sr + $1 \mathrm{mM} \mathrm{Ag}(\mathrm{pH}=5)$ & 66.1 & 30.0 & 0 & 2.2 & 1.6 & 0.2 \\
\hline $\mathrm{NaOH}-\mathrm{Ca}+$ Sr-heat-Sr $+1 \mathrm{mM} \mathrm{Ag}(\mathrm{pH}=6)$ & 66.3 & 29.8 & 0 & 2.1 & 1.6 & 0.2 \\
\hline $\mathrm{NaOH}-\mathrm{Ca}+$ Sr-heat-Sr $+1 \mathrm{mM} \mathrm{Ag}(\mathrm{pH}=7)$ & 65.6 & 30.6 & 0 & 2.1 & 1.6 & 0.1 \\
\hline $\mathrm{NaOH}-\mathrm{Ca}+$ Sr-heat-Sr+1 mM Ag $(\mathrm{pH}=8)$ & 65.7 & 30.4 & 0 & 2.1 & 1.7 & 0.1 \\
\hline $\mathrm{NaOH}-\mathrm{Ca}+$ Sr-heat-Sr & 68.7 & 27.4 & 0 & 2.2 & 1.7 & 0 \\
\hline
\end{tabular}

The standard deviation of each element is as follows $\left(\mathrm{SD}_{i}: i\right.$ indicates individual element). $\mathrm{SD}_{\mathrm{O}}<0.44, \mathrm{SD}_{\mathrm{Ti}}<0.44$, $\mathrm{SD}_{\mathrm{Ca}}<0.12, \mathrm{SD}_{\mathrm{Sr}}<0.11, \mathrm{SD}_{\mathrm{Ag}}<0.08$.

The surface structure of these samples was examined by XRD analysis and Raman scattering as shown in Figure 1. Sodium hydrogen titanate (SHT; $\mathrm{Na}_{x} \mathrm{H}_{2-x} \mathrm{Ti}_{3} \mathrm{O}_{7}$ ) was produced after the initial $\mathrm{NaOH}$ treatment. These XRD and Raman profiles were not apparently changed except for a slight shift of about 920 to $900 \mathrm{~cm}^{-1}$ in Raman by the subsequent $\mathrm{Ca}+\mathrm{Sr}$ treatment. Since the Raman peak around $920 \mathrm{~cm}^{-1}$ in SHT was attributed to Ti-O bonds coordinated with Na ions [35], the results indicate that 
the SHT transformed into Sr-containing calcium hydrogen titanate by replacing $\mathrm{Na}$ with $\mathrm{Ca}$ and $\mathrm{Sr}$ without any apparent change of its structural frame. This material was dehydrated by the subsequent heat treatment to form Sr-containing calcium titanate and rutile accompanied by a small quantity of anatase. Although the XRD and Raman profiles were apparently unchanged by the final $\mathrm{Sr}+1 \mathrm{mM} \mathrm{Ag}$ treatment regardless of the $\mathrm{pH}$ of the solution, it may be inferred that the Sr-containing calcium titanate transformed into Sr- and Ag-containing calcium titanate or Sr- and Ag-containing calcium-deficient calcium titanate by a final solution treatment with a $\mathrm{pH} \geq 5$ or $\mathrm{pH} \leq 4$, respectively, according to surface chemical composition, as shown in Table 2. When these samples were subjected to scratch resistance test, the surface layer formed after the first $\mathrm{NaOH}$ treatment showed low scratch resistance value as $0.9 \pm 0.5 \mathrm{mN}$. This value was almost unchanged by the second solution treatment (the value was $1.6 \pm 0.5 \mathrm{mN}$ ). In contrast, it markedly increased to $37.8 \pm 7.0 \mathrm{mN}$ after heat and remained even after the $\mathrm{Sr}+1 \mathrm{mM} \mathrm{Ag}(\mathrm{pH}=4)$ treatment (the value was $39.3 \pm 3.7 \mathrm{mN})$.

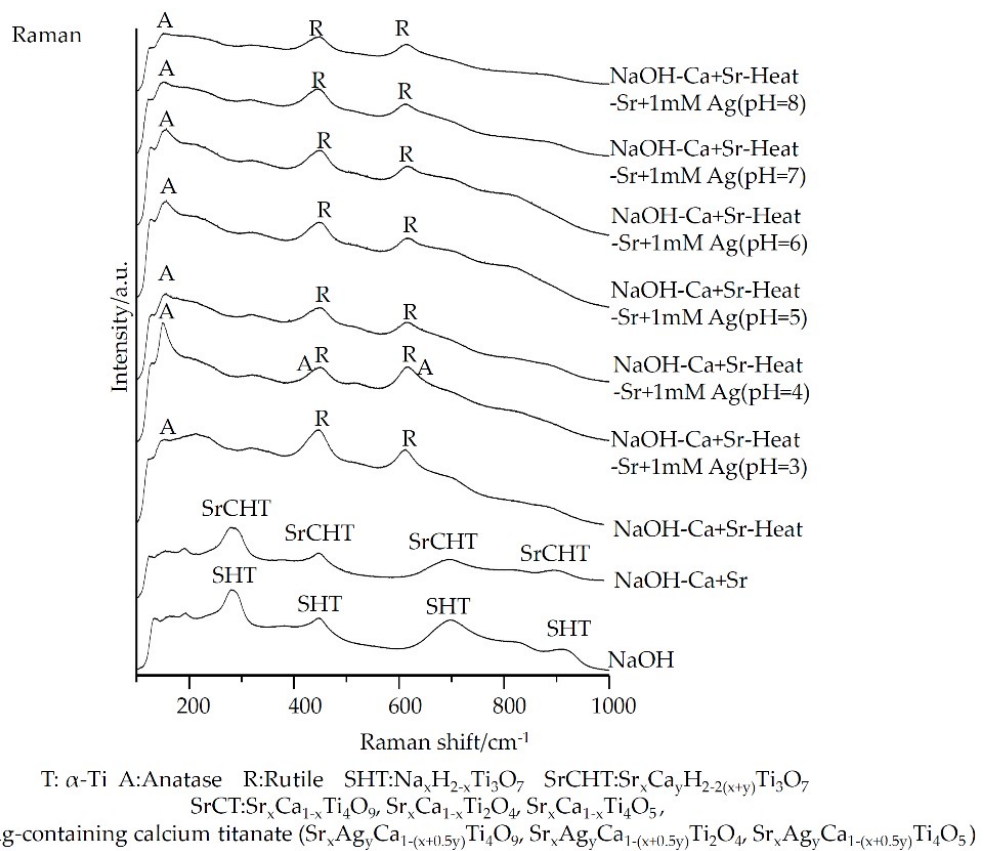

$\boldsymbol{\nabla}$ : Sr- and Ag-containing calcium titanate $\left(\mathrm{Sr}_{\mathrm{x}} \mathrm{Ag}_{\mathrm{y}} \mathrm{Ca}_{1-(\mathrm{x}+0.5 \mathrm{y})} \mathrm{Ti}_{4} \mathrm{O}_{9}, \mathrm{Sr}_{\mathrm{x}} \mathrm{Ag}_{\mathrm{y}} \mathrm{Ca}_{1-(\mathrm{x}+0.5 \mathrm{y})} \mathrm{Ti}_{2} \mathrm{O}_{4}, \mathrm{Sr}_{\mathrm{x}} \mathrm{Ag}_{\mathrm{y}} \mathrm{Ca}_{1-(\mathrm{x}+0.5 \mathrm{y})} \mathrm{Ti}_{4} \mathrm{O}_{5}\right)$

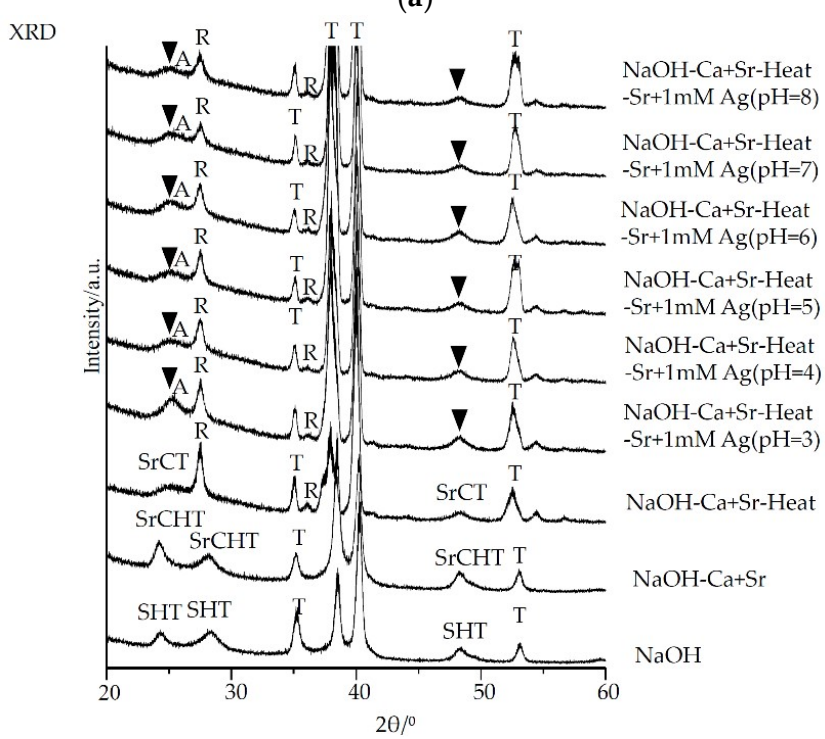

(b)

Figure 1. Raman (a) and XRD (b) spectra of Ti surfaces subjected to $\mathrm{Sr}+1 \mathrm{mM} \mathrm{Ag}$ treatment with various $\mathrm{pH}$ following $\mathrm{NaOH}, \mathrm{Ca}+\mathrm{Sr}$ and heat treatment. 
Depth profile of XPS analysis on the metal sample after the NaOH-Ca + Sr-heat-Sr $+1 \mathrm{mM} \mathrm{Ag}$ $(\mathrm{pH}=4)$ is shown in Figure 2. Comparable amounts of $\mathrm{Sr}$ and $\mathrm{Ca}$ and a small amount of Ag were detected near the top surface and decreased gradually in depth until approximately $1 \mu \mathrm{m}$. The results are consistent with the surface chemical composition in Table 2, and the thickness of the surface layer on cross sectional SEM observation, where an approximately $1 \mu \mathrm{m}$ thick surface layer was evident (data not shown). Figure 3 shows narrow XPS spectra of the treated metal. The peaks at 367.7 and $373.8 \mathrm{eV}$ attributed to $\mathrm{Ag}_{2} \mathrm{O}$ [36] were observed, verifying that $\mathrm{Ag}$ was incorporated into the surface as a form of $\mathrm{Ag}^{+}$ion.

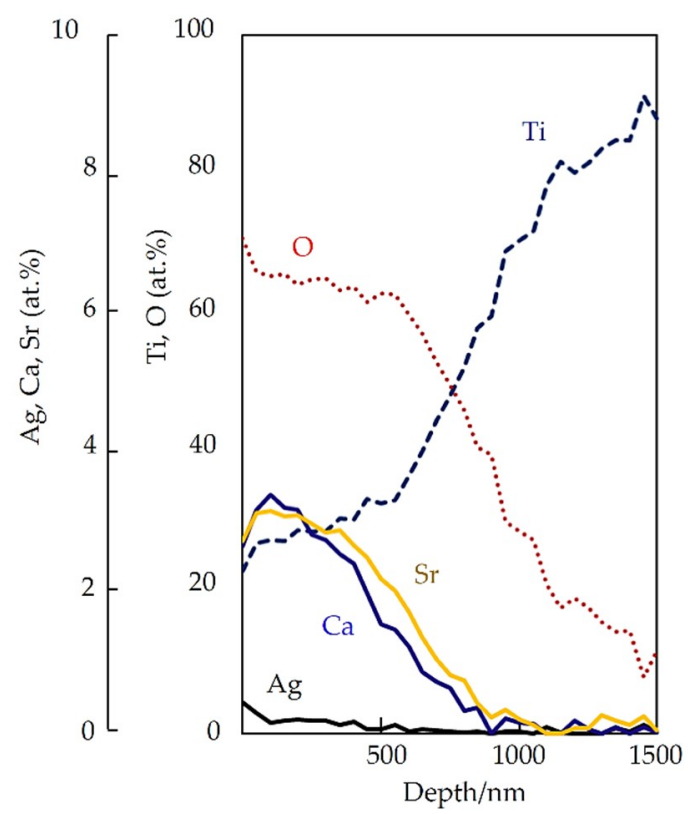

Figure 2. XPS depth profile of the surface of Ti subjected to $\mathrm{NaOH}-\mathrm{Ca}+\mathrm{Sr}-$ heat-Sr $+1 \mathrm{mM} \mathrm{Ag}(\mathrm{pH}=4)$.

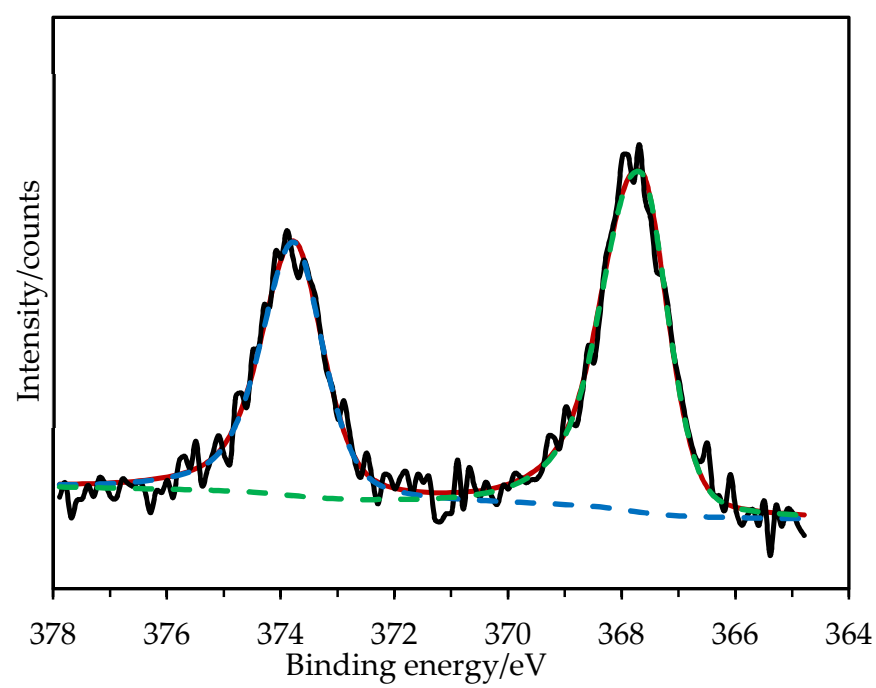

Figure 3. Narrow XPS Ag $3 d$ profile of Ti surface subjected to $\mathrm{NaOH}-\mathrm{Ca}+\mathrm{Sr}-\mathrm{heat}-\mathrm{Sr}+1 \mathrm{mM} \mathrm{Ag}$ $(\mathrm{pH}=4)$. Red solid line: composite line of blue and green dot lines, Blue dot line: deconvolution line of $\mathrm{Ag} 3 d_{3 / 2}$, Green dot line: deconvolution line of $\mathrm{Ag} 3 d_{5 / 2}$.

Figure 4 shows the SEM images of the Ti surface before and after soaking in SBF for 3 days that was subjected to $\mathrm{Sr}+1 \mathrm{mM} \mathrm{Ag}$ treatment with various $\mathrm{pH}$ levels following $\mathrm{NaOH}, \mathrm{CaCl}_{2}$, and heat treatment. It can be seen that a similar network morphology on a nanometer scale was produced by the aqueous solution and heat treatment regardless of the $\mathrm{pH}$ of the $1 \mathrm{M} \mathrm{Sr}\left(\mathrm{NO}_{3}\right)_{2}+1 \mathrm{mM} \mathrm{AgNO}$ 
solution used in the final solution treatment. When the treated metals were immersed in SBF for 3 days, apatite formation was observed only on the surfaces that had been treated with $1 \mathrm{M} \mathrm{Sr}\left(\mathrm{NO}_{3}\right)_{2}$ and $1 \mathrm{mM} \mathrm{AgNO}{ }_{3}$ with a $\mathrm{pH}$ equal to or less than 4 . In terms of apatite formation as well as the $\mathrm{Ag}$ and $\mathrm{Sr}$ content, the $\mathrm{pH}$ of the aqueous solution was fixed at 4 in the following experiment.

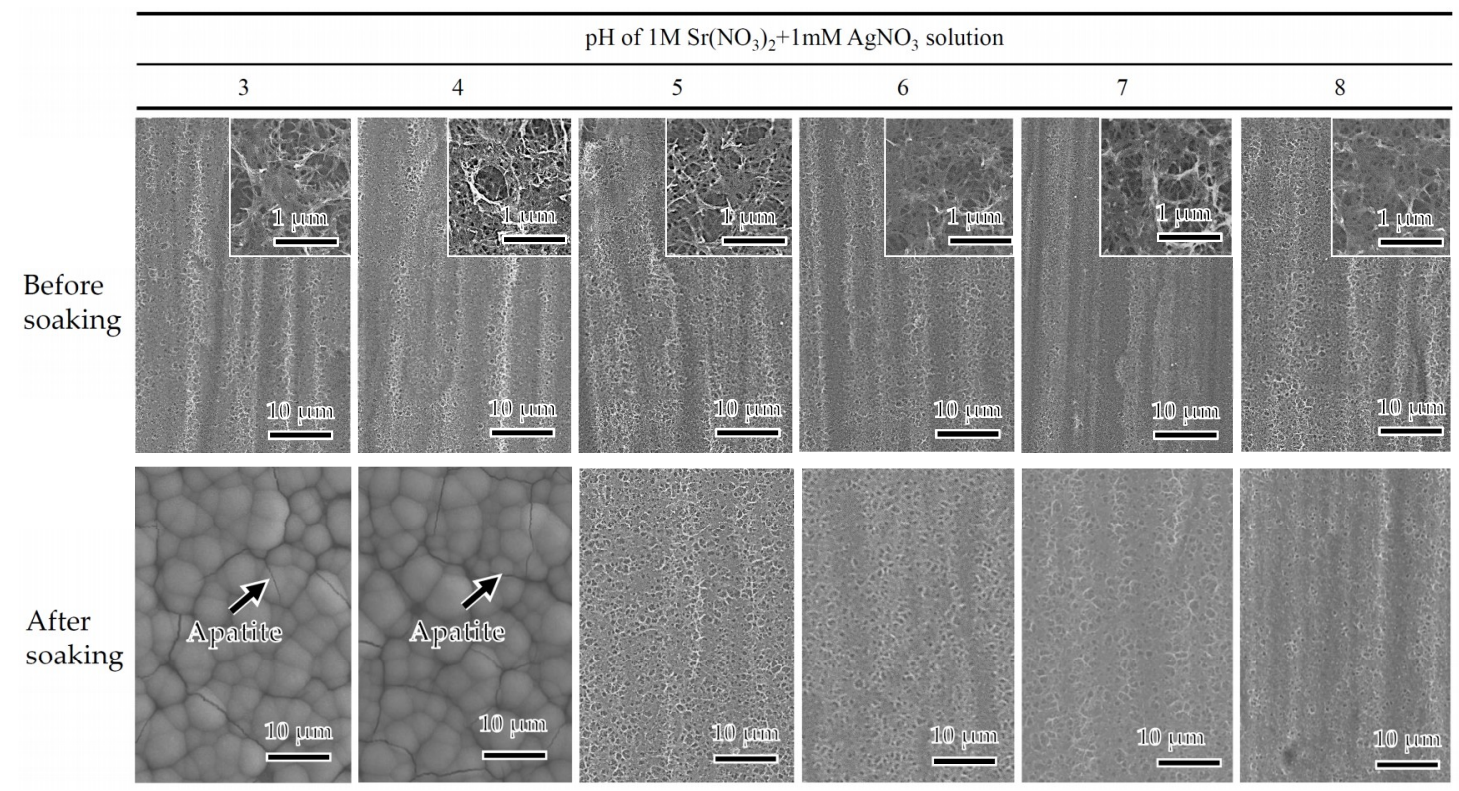

Figure 4. SEM images of the surfaces of Ti before and after soaking in SBF for 3 days that has been subjected to $\mathrm{Sr}+1 \mathrm{mM} \mathrm{Ag}$ treatment with various $\mathrm{pH}$ following $\mathrm{NaOH}, \mathrm{Ca}+\mathrm{Sr}$ and heat treatment. Small windows show high magnification images on Ti before soaking in SBF. The digits in the table above the images stand for $\mathrm{pH}$ of $1 \mathrm{M} \mathrm{Sr}\left(\mathrm{NO}_{3}\right)_{2}+1 \mathrm{mM} \mathrm{AgNO}_{3}$ solution in the final solution treatment.

\subsection{Effect of the Ag Concentration in the Solution Treatment on Apatite Formation}

The Ti samples subjected to the $\mathrm{NaOH}-\mathrm{Ca}+\mathrm{Sr}$-heat treatment were soaked in a $1 \mathrm{M} \mathrm{Sr}\left(\mathrm{NO}_{3}\right)_{2}$ solution of $\mathrm{pH}=4$ with different concentrations of $\mathrm{AgNO}_{3}$ from 1 to $100 \mathrm{mM}$ added, and their surface chemical composition was analyzed by EDX, as shown in Table 3. The amount of Ag increased, with increasing concentration of $\mathrm{Ag}$ in the final solution treatment up to $1.1 \%$ along with slightly decreased Sr content.

Table 3. The results of EDX analysis on the surface of Ti subjected to $\mathrm{Sr}+\mathrm{XmM} \mathrm{Ag}(\mathrm{pH}=4)$ treatment $(X=1-100)$ following $\mathrm{NaOH}, \mathrm{Ca}+\mathrm{Sr}$ and heat treatment.

\begin{tabular}{|c|c|c|c|c|c|}
\hline \multirow{2}{*}{ Treatment } & \multicolumn{5}{|c|}{ Element/at.\% } \\
\hline & $\mathbf{O}$ & $\mathrm{Ti}$ & $\mathrm{Ca}$ & Sr & Ag \\
\hline $\mathrm{NaOH}-\mathrm{Ca}+$ Sr-heat-Sr $+1 \mathrm{mM} \mathrm{Ag}(\mathrm{pH}=4)$ & 65.8 & 30.5 & 1.9 & 1.6 & 0.2 \\
\hline $\mathrm{NaOH}-\mathrm{Ca}+$ Sr-heat-Sr $+2 \mathrm{mM} \mathrm{Ag}(\mathrm{pH}=4)$ & 66.1 & 30.3 & 1.9 & 1.5 & 0.2 \\
\hline $\mathrm{NaOH}-\mathrm{Ca}+$ Sr-heat-Sr $+5 \mathrm{mM} \mathrm{Ag}(\mathrm{pH}=4)$ & 66.1 & 30.3 & 1.9 & 1.5 & 0.3 \\
\hline $\mathrm{NaOH}-\mathrm{Ca}+$ Sr-heat-Sr + $10 \mathrm{mM} \mathrm{Ag}(\mathrm{pH}=4)$ & 66.3 & 30.2 & 1.8 & 1.4 & 0.3 \\
\hline $\mathrm{NaOH}-\mathrm{Ca}+$ Sr-heat-Sr + $20 \mathrm{mM} \mathrm{Ag}(\mathrm{pH}=4)$ & 66.1 & 30.2 & 1.9 & 1.4 & 0.4 \\
\hline $\mathrm{NaOH}-\mathrm{Ca}+$ Sr-heat-Sr + $50 \mathrm{mM} \mathrm{Ag}(\mathrm{pH}=4)$ & 66.1 & 29.6 & 2.0 & 1.5 & 0.9 \\
\hline $\mathrm{NaOH}-\mathrm{Ca}+$ Sr-heat-Sr + $100 \mathrm{mM} \mathrm{Ag}(\mathrm{pH}=4)$ & 65.7 & 29.9 & 2.0 & 1.3 & 1.1 \\
\hline
\end{tabular}

The standard deviation of each element is as follows $\left(\mathrm{SD}_{i}: i\right.$ indicates individual element). $\mathrm{SD}_{\mathrm{O}}<0.6, \mathrm{SD}_{\mathrm{Ti}}<0.4$, $\mathrm{SD}_{\mathrm{Ca}}<0.1, \mathrm{SD}_{\mathrm{Sr}}<0.1, \mathrm{SD}_{\mathrm{Ag}}<0.1$.

SEM revealed that nano sized particles started to be precipitated on the surface of Ti when the Ag concentration in the final solution treatment was $20 \mathrm{mM}$, and their number increased with an increasing Ag concentration, as shown in Figure 5. These particles were determined to be metallic Ag 
particles by EDX line analysis (data not shown). It can be seen from the XRD and Raman spectra of the treated samples (Figure 6) that a peak at around $44^{\circ}$ attributed to metallic $\mathrm{Ag}$ [37] was detected on the Ti surface only when the Ag concentration in the final solution treatment was equal or greater than $20 \mathrm{mM}$. There were no other changes that depended on the Ag concentration of the final solution treatment in the XRD and Raman profiles.

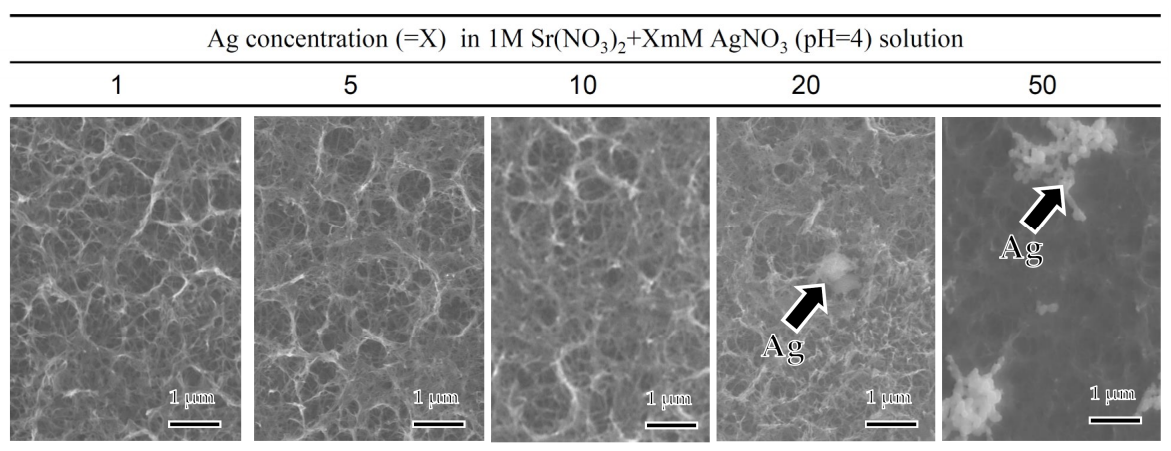

Figure 5. SEM images of the surfaces of Ti subjected to $\mathrm{Sr}+X \mathrm{mM} \mathrm{Ag}(\mathrm{pH}=4)$ treatment $(X=1-50)$ following $\mathrm{NaOH}, \mathrm{Ca}+\mathrm{Sr}$ and heat treatment.

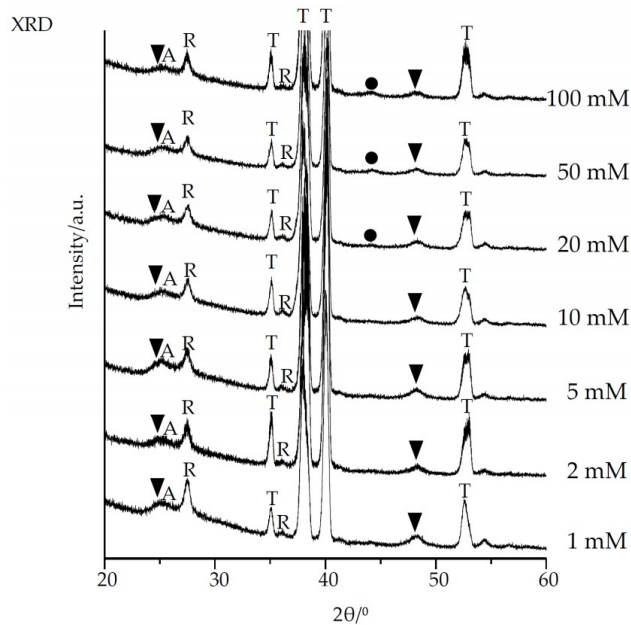

(a)

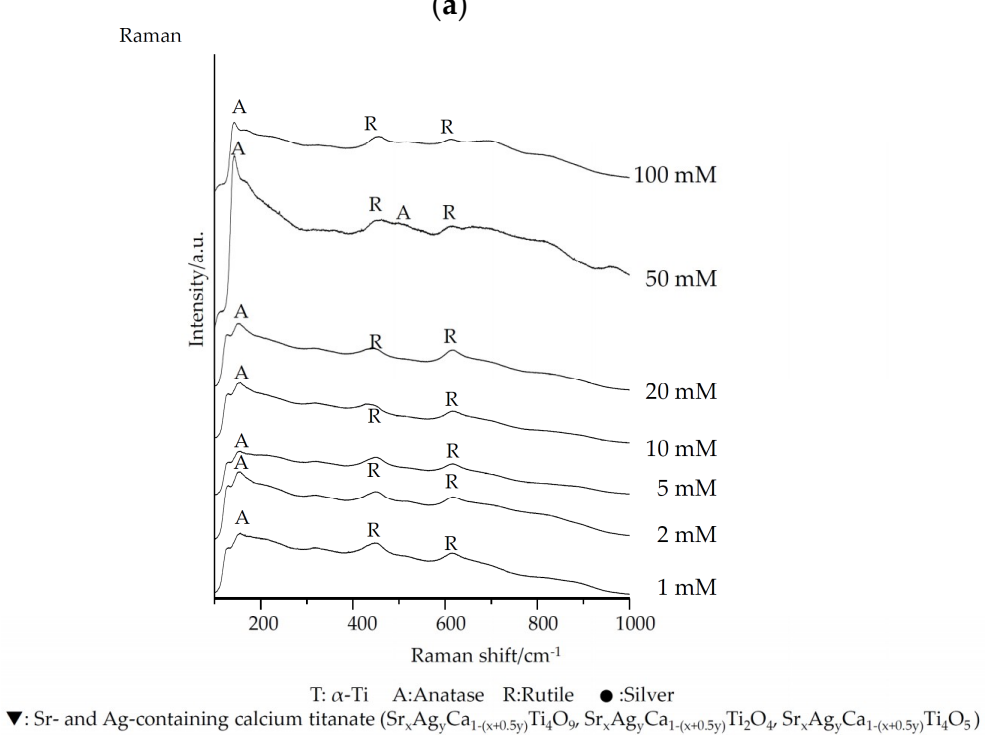

(b)

Figure 6. XRD (a) and Raman (b) spectra of Ti surfaces subjected to $\mathrm{Sr}+\mathrm{X} \mathrm{mM} \mathrm{Ag}(\mathrm{pH}=4)$ treatment with various $\mathrm{Ag}$ concentrations $(X=1-100)$ following $\mathrm{NaOH}, \mathrm{Ca}+\mathrm{Sr}$ and heat treatment. 
When these samples were soaked in SBF, they formed spherical particles on their surfaces within 3 days that were identified as low crystalline apatite by XRD (data not shown), regardless of the Ag content and even in the presence of Ag particles as shown in Figure 7.

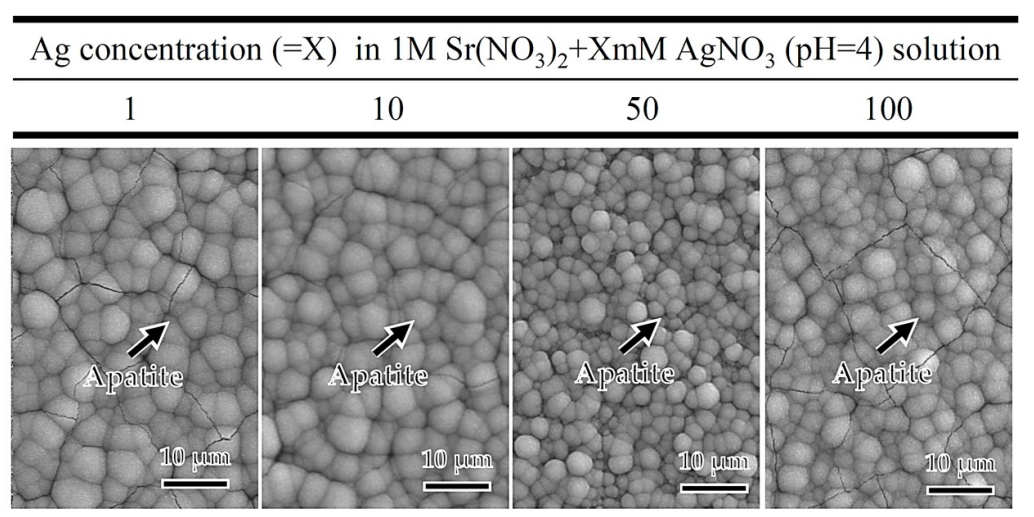

Figure 7. SEM images of the surface of Ti before and after soaked in SBF for 3 days that has been subjected to $\mathrm{Sr}+X \mathrm{mM} \mathrm{Ag}(\mathrm{pH}=4)$ treatment with various Ag concentrations $(X=1-50)$ following $\mathrm{NaOH}, \mathrm{CaCl}_{2}$, and heat treatment.

\subsection{Effect of the Ag Concentration in the Solution on Cytotoxicity}

The Ti samples with Sr- and Ag-containing calcium-deficient calcium titanate without any metallic Ag particles were prepared by $\mathrm{Sr}+1 \mathrm{mM} \mathrm{Ag}(\mathrm{pH}=4)$ or $\mathrm{Sr}+10 \mathrm{mM} \mathrm{Ag}(\mathrm{pH}=4)$ treatment following $\mathrm{NaOH}-\mathrm{Ca}+\mathrm{Sr}-$ heat treatment, and their effect on the viability of MC3T3-E1 cells was examined. The results were compared with those on untreated or $\mathrm{NaOH}-\mathrm{Ca}+\mathrm{Sr}$-heat-Sr-treated Ti with Sr-containing calcium titanate free of Ag. As shown in Figure 8, the cell viability significantly increased in the treated Ti subjected to $\mathrm{NaOH}-\mathrm{Ca}+\mathrm{Sr}-$ heat- $\mathrm{Sr}+1 \mathrm{mM} \mathrm{Ag}(\mathrm{pH}=4)$ compared with untreated samples in the culture period of 1 day. There were no significant differences between the treated samples. At 3 days, although all of the treated samples showed higher cell viability than the untreated sample, there was a difference between the treated samples: $\mathrm{NaOH}-\mathrm{Ca}+\mathrm{Sr}$-heat-Sr was highest, followed by $\mathrm{NaOH}-\mathrm{Ca}$ + Sr-heat-Sr $+1 \mathrm{mM} \mathrm{Ag}(\mathrm{pH}=4)$ and then $\mathrm{NaOH}-\mathrm{Ca}+\mathrm{Sr}-$ heat-Sr $+10 \mathrm{mM} \mathrm{Ag}(\mathrm{pH}=4)$. There a significant difference between Ti samples subjected to the NaOH-Ca $+\mathrm{Sr}-$ heat-Sr and NaOH-Ca + Sr-heat-Sr $+10 \mathrm{mM} \mathrm{Ag}(\mathrm{pH}=4)$ treatments.

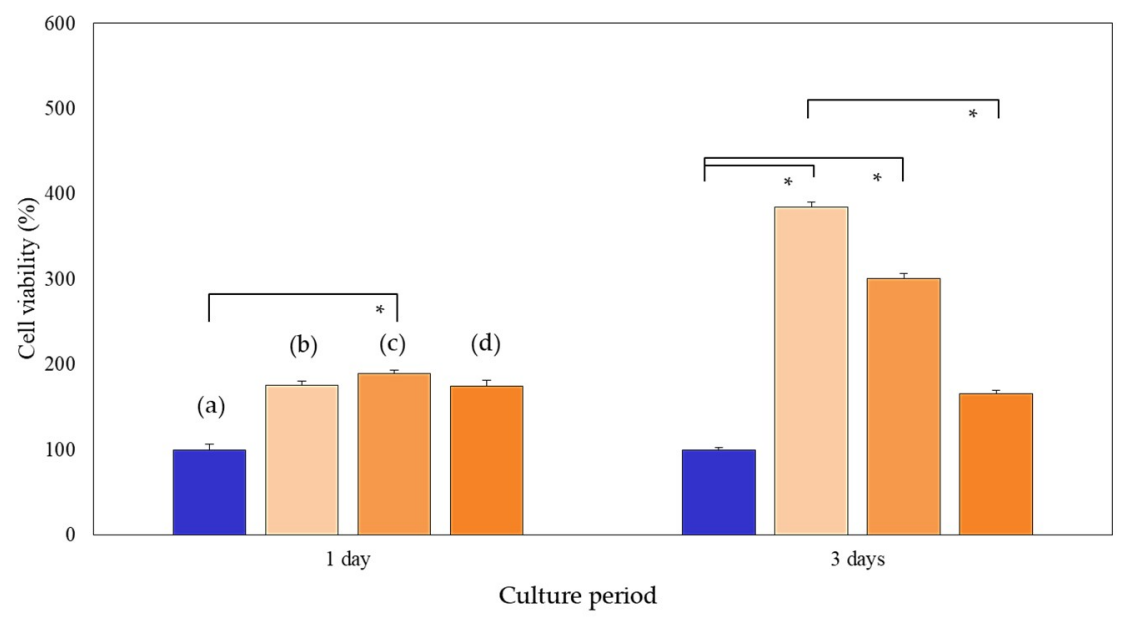

Figure 8. Cell viability of MC3T3-E1 on Ti (a) untreated and subjected to (b) $\mathrm{NaOH}-\mathrm{CaCl}_{2}$-heat-Sr, (c) $\mathrm{NaOH}-\mathrm{CaCl}_{2}$-heat-Sr $+1 \mathrm{mMAg}(\mathrm{pH}=4)$, and (d) NaOH-CaCl -heat-Sr $+10 \mathrm{mM} \mathrm{Ag}(\mathrm{pH}=4)$. Asterisk stands for statistically significant difference $(p<0.05)$. 


\subsection{Antibacterial Activity}

The antibacterial activity against $E$. coli of the Ti subjected to $\mathrm{NaOH}-\mathrm{Ca}+\mathrm{Sr}-$ heat-Sr $+1 \mathrm{mM}$ $\mathrm{Ag}(\mathrm{pH}=4)$ was examined by the film contact method. As a result, the treated Ti displayed a 5.9-log reduction compared with the untreated $\mathrm{Ti}$, as shown in Table 4, indicating sufficiently high antibacterial activity.

Table 4. Antibacterial activity results on Ti untreated and subjected to $\mathrm{NaOH}-\mathrm{Ca}+\mathrm{Sr}-\mathrm{heat}-\mathrm{Sr}+1 \mathrm{mM}$ $\mathrm{Ag}(\mathrm{pH}=4)$.

\begin{tabular}{cccc}
\hline Treatment & \multicolumn{2}{c}{ Average of E. Coli count/CFU } & Antibacterial Activity \\
& After Inoculation & After Incubation & Value \\
\hline Untreated & $2.8 \times 10^{6}$ & $1.5 \times 10^{7}$ & - \\
$\mathrm{NaOH}-\mathrm{Ca}+\mathrm{Sr}-$ heat-Sr $+1 \mathrm{mM} \mathrm{Ag}(\mathrm{pH}=4)$ & $4.7 \times 10^{6}$ & $<20$ & 5.9 \\
\hline
\end{tabular}

\subsection{Ion Release Test}

The same treated samples were soaked in FBS for up to 14 days and the $\mathrm{Sr}$ and Ag ions released from the samples were measured by ICP. It can be seen in Figure 9 that the treated metal released $0.78 \mathrm{ppm}$ of $\mathrm{Ag}$ and $0.87 \mathrm{ppm}$ of $\mathrm{Sr}$ within $1 \mathrm{~h}$, and then slowly released another $0.91 \mathrm{ppm}$ of $\mathrm{Ag}$ and $0.42 \mathrm{ppm}$ of Sr over 14 days.

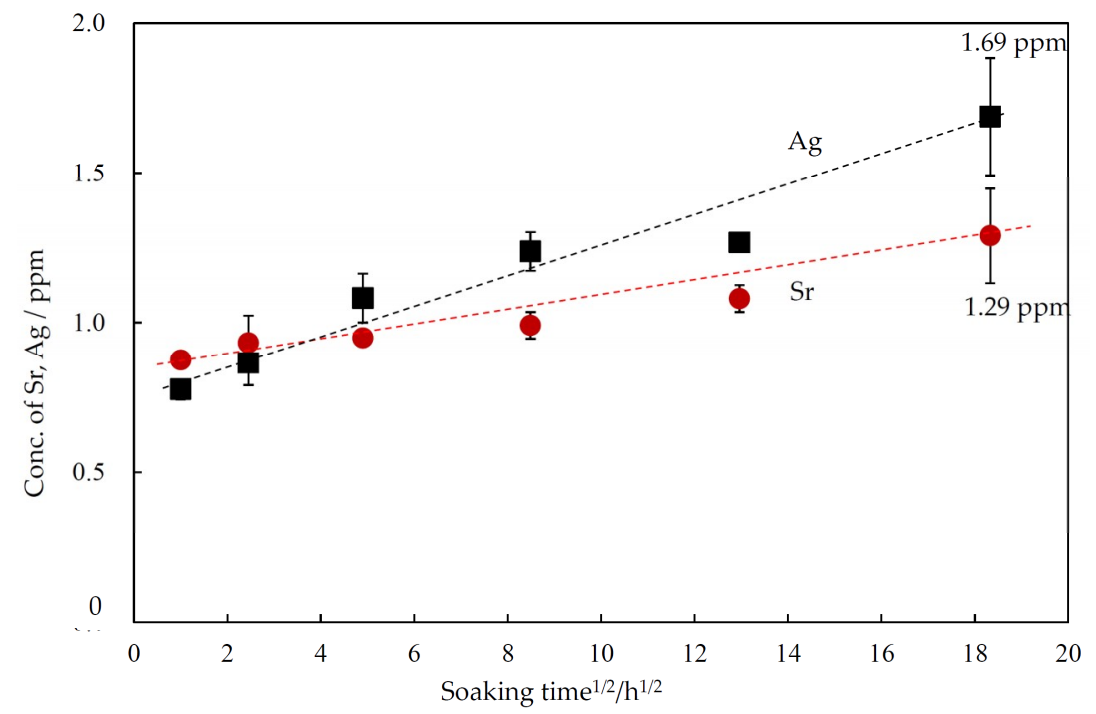

Figure 9. Concentrations of $\mathrm{Sr}$ and $\mathrm{Ag}$ ions released from Ti subjected $\mathrm{NaOH}-\mathrm{CaCl}_{2}$-heat-Sr $+1 \mathrm{mM}$ $\mathrm{Ag}(\mathrm{pH}=4)$, as a function of square root of soaking time in FBS, which was measured by ICP. Black squares and red circles indicate Ag and Sr, respectively.

\section{Discussion}

The SHT $\left(\mathrm{Na}_{x} \mathrm{H}_{2-x} \mathrm{Ti}_{3} \mathrm{O}_{7}\right)$ formed on Ti and its alloys by $\mathrm{NaOH}$ treatment has potent ion exchange capacity because of its layered structure [38]. It has been reported that the $\mathrm{Na}^{+}$in SHT can be exchanged by various types of and even various valences of metal ions such as $\mathrm{Ag}^{+}$, magnesium $\left(\mathrm{Mg}^{2+}\right), \mathrm{Ca}^{2+}$, $\mathrm{Sr}^{2+}$, gallium $\left(\mathrm{Ga}^{3+}\right)$, and more than two types of them simultaneously [27-30,39-42]. The present study proved that even three types of functional ions such as $\mathrm{Ca}$, Sr and Ag can be controllably incorporated into the surface of Ti by a combination of simple aqueous solution and heat treatment.

The incorporation of $\mathrm{Ag}^{+}$ions into SHT was first attempted by Inoue et al. [43]. They formed an Ag-containing sodium titanate layer by soaking $\mathrm{Ti}$ in $0.05 \mathrm{M}$ silver acetate solution following $\mathrm{NaOH}$ solution or $\mathrm{NaOH}$ hydrothermal treatment. The treated metal contained $\mathrm{Ag}^{+}$ions, but also a certain amount of precipitated metallic silver particles [43]. Such colloidal metallic particles are undesirable because they could be released and transferred to other organ, resulting in side effects. 
Kizuki et al. [28] and Prabu et al. [44] demonstrated that Ag can be induced into SHT formed on Ti and Ti-6Al-4V alloy as ion form by soaking the metals in $0.01-100 \mathrm{mM} \mathrm{Ag}(\mathrm{NO})_{3}$ solution after the $\mathrm{NaOH}$ solution. However, metallic Ag particles were formed again when the treated metals were subsequently heat-treated at $600{ }^{\circ} \mathrm{C}$ [28]. Eventually, Ag-containing calcium titanate free of Ag particles forms on Ti and Ti-15Zr-4Nb-4Ta alloy as the result of immersing in $1 \mathrm{mM} \mathrm{AgNO}_{3}$ solution following $\mathrm{NaOH}-\mathrm{CaCl}_{2}$-heat treatment [28]. The treated Ti and $\mathrm{Ti}-15 \mathrm{Zr}-4 \mathrm{Nb}-4 \mathrm{Ta}$ contained $0.55 \%$ and $0.27 \%$ of $\mathrm{Ag}$ on their surfaces and released 2.66 and $1.45 \mathrm{ppm}$ of $\mathrm{Ag}^{+}$ions into FBS, respectively. These metals showed strong antibacterial activity against S. aureus (more than $99 \%$ reduction). However, the cytotoxicity of these treated metals was not reported.

In the present study, Ti along with Sr- and Ag-containing calcium titanate with various amounts of Ag were produced. It is shown in Table 3 and Figures 5 and 6 that the Ag content increased from $0.2 \%$ to $1.1 \%$ in the final solution treatment, while metallic Ag precipitated when the Ag content on the surface of Ti became $0.4 \%$. Thus, Ti specimens with the surface containing $0.2 \%$ and $0.3 \% \mathrm{Ag}$ in the ion form were prepared and their cytotoxicity compared with the untreated and the Ag free Ti with the Sr-containing calcium titanate. As a result, the Ti with the Sr-containing calcium titanate was shown to markedly increase the cell viability after 3 days compared with the untreated Ti. This is consistent with our previous report in which the cell viability in the Ti subjected to the same treatment was significantly increased compared with untreated Ti on 5 days [45]. A similar increase in cell viability was observed in the case of Ti with $0.2 \% \mathrm{Ag}$ at 1 and 3 days. In contrast, the cell viability of Ti with $0.3 \% \mathrm{Ag}$ was significantly lower than that of Ti with Sr-containing calcium titanate, although it was comparable to that of untreated Ti. This is probably because the $\mathrm{Ag}^{+}$ions that were released from the surface of the treated Ti accumulated in the vicinity of the surface and suppressed cell proliferation. The Ti with the $0.2 \%$ Ag resulting from $\mathrm{NaOH}-\mathrm{Ca}+\mathrm{Sr}-$ heat-Sr $+1 \mathrm{mM} \mathrm{Ag}(\mathrm{pH}=4)$ slowly released $1.69 \mathrm{ppm}$ $\mathrm{Ag}^{+}$ions into FBS over 14 days and exhibited potent antibacterial activity against $E$. coli, as shown in Figure 9 and Table 4 . It has been reported that Ti and its alloys with $0.27 \%-0.67 \%$ Ag content induced by chemical and heat treatment exhibited strong antibacterial activity without any cytotoxicity [46]. The results in this study are consistent with these reports. On the other hand, they also imply that a lower Ag content, such as $0.3 \%$, may suppress cell proliferation without any cytotoxicity.

Bone-bonding is a crucial function of an implant and may be predicted by examining the apatite formation on the material that occurs in SBF [33]. Fujibayashi et al. reported that bioactive $\mathrm{Na}_{2} \mathrm{O}-\mathrm{CaO}-\mathrm{SiO}_{2}$ glass powders with different compositions and induction periods of apatite formation in SBF induced different amount of new bone formation: amount of new bone formation increased with decreasing induction periods of apatite formation in SBF [47]. They recommended the materials able to form apatite within 3 days in SBF for practical use. It should be noted that the bone-bonding strength might be affected by various factors including strength and thickness of the substrate and coating layers [48]. It was reported that $\mathrm{Ti}-15 \mathrm{Zr}-4 \mathrm{Nb}-4 \mathrm{Ta}$ alloy with approximately $0.5 \mu \mathrm{m}$ calcium-deficient calcium titanate layer implanted into rabbit tibia showed lower critical detaching load in detaching test than Ti with approximately $1 \mu \mathrm{m}$ calcium-deficient calcium titanate layer at 4 weeks of implantation period, although both of them exhibited direct bone-bonding in histological observation $[19,20]$. The critical detaching load increased with increasing implantation periods up to 26 weeks in both cases, where fracture occurred not at interfaces between the treated metals and bone but inside the bone [20]. In this study, abundant apatite formation was observed on the treated Ti within 3 days in SBF regardless of the Ag content and even in the presence of metallic Ag particles. Sufficiently high bone-bonding is expected on these metals. On the other hand, apatite formation strongly depended on the $\mathrm{pH}$ of the solution in the final solution treatment: Ti formed apatite only when it had been soaked in $1 \mathrm{M}$ $\mathrm{Sr}\left(\mathrm{NO}_{3}\right)_{2}$ and $1 \mathrm{mM} \mathrm{AgNO}$ with a $\mathrm{pH}$ equal to or less than 4, as shown in Figure 7 . This might be due to the formation of Sr- and Ag-containing calcium-deficient calcium titanate on Ti. It is reported that the calcium-deficient calcium titanate that forms on Ti exhibits an increased capacity for apatite formation compared with calcium titanate because of its greater release of $\mathrm{Ca}^{2+}$ ions [28,41]. 
It is expected that new bone growth surrounding Ti will be accelerated if appropriate concentrations of $\mathrm{Sr}^{2+}$ ions are released from $\mathrm{Ti}$ in the living body. The new bone tightly bonds to the metal via the apatite that have been formed on the metal surface. In the present study, the Ti subjected to $\mathrm{NaOH}-\mathrm{Ca}$ + Sr-heat-Sr $+1 \mathrm{mM} \mathrm{Ag}(\mathrm{pH}=4)$ slowly released $1.29 \mathrm{ppm}$ of $\mathrm{Sr}^{2+}$ ions into FBS in addition to $\mathrm{Ag}^{+}$ions over 14 days. This value falls in the effective range of 0.21 and $21.07 \mathrm{ppm}$ that was shown to enhance the expression of a key osteoblast transcription factor gene (Cbfa1) and alkaline phosphatase (ALP) activity in human bone marrow mesenchymal stem cells [49]. Park et al. hydrothermally produced $\mathrm{SrTiO}_{3}$ coating on Ti that released $0.75 \mathrm{ppm}$ of $\mathrm{Sr}^{2+}$ ions into physiological saline solution. When primary mouse bone marrow stromal cells were cultured on the metal surface, increased cell activity including cell attachment, spreading, gene expression, and ALP activity was shown [30]. Yamaguchi et al. [29] and Okuzu et al. [45] reported that Ti having Sr-containing calcium titanate on its surface increased

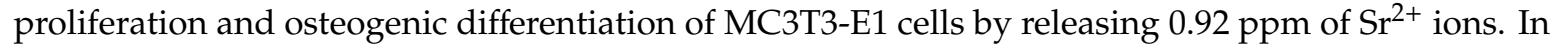
their reports, various types of gene expression, including integrin $\beta 1, \beta$ catenin, cyclin D1 and ALP were up-regulated and resulted in extracellular mineralization. They also showed that biomechanical strength as well as bone-implant contact became greater than the Ti with calcium-deficient calcium titanate, when the metals were implanted into rabbit tibia at short periods of 4-8 weeks.

Based on these results, the Ti with Sr- and Ag-containing calcium-deficient calcium titanate is expected to form apatite on its surface and bond to living bone through the apatite, while promoting new bone growth by releasing $\mathrm{Sr}^{2+}$ ions. Furthermore, it should prevent postoperative infection because of its antibacterial activity.

\section{Conclusions}

Tri-functional bioactive Ti with the Sr- and Ag-containing calcium-deficient calcium titanate was produced by a combination of aqueous solution and heat treatment. An effective amount of $\mathrm{Ca}$, $\mathrm{Sr}$ and Ag was introduced into the surface of Ti by controlling the ion concentration and $\mathrm{pH}$ of the solution so that the treated Ti precipitated apatite in SBF within 3 days and exhibited strong antibacterial activity, with increased cell viability. Furthermore, it released $\mathrm{Sr}^{2+}$ ions into FBS at a level up to $1.29 \mathrm{ppm}$. This type of multifunctional Ti is promising for the next generation of orthopedic and dental implants in next generation.

Author Contributions: Conceptualization, S.Y., M.I., S.A.S. and H.T.; Methodology, S.Y., P.T.M.L. and M.I.; Software, S.Y. and S.A.S.; Validation, S.Y., P.T.M.L., M.I. and S.A.S.; Formal Analysis, S.Y., M.I. and S.A.S.; Investigation, S.Y., P.T.M.L. and M.I.; Resources, S.Y. and M.I.; Data Curation, S.Y. and S.A.S.; Writing-Original Draft Preparation, S.Y.; Writing—Review and Editing, S.Y.; Visualization, S.Y.; Supervision, M.I. and H.T.; Project Administration, S.Y.; Funding Acquisition, S.Y.

Funding: This research was partially supported by Chubu University Grant (B) 19M02B.

Conflicts of Interest: The authors declare no conflict of interest.

\section{References}

1. Hacking, S.A.; Tanzer, M.; Harvey, E.J.; Krygier, J.J.; Bobyn, J.D. Relative contributions of chemistry and topography to the osseointegration of hydroxyapatite coatings. Clin. Orthopaed. Relat. Res. 2002, 405, $24-38$. [CrossRef] [PubMed]

2. Coelho, P.G.; Granjeiro, J.M.; Romanos, G.E.; Suzuki, M.; Silva, N.R.F.; Cardaropoli, G.; Thompson, V.P.; Lemons, J.E. Basic research methods and current trends of dental implant surfaces. J. Biomed. Mater. Res. 2009, 88, 579-596. [CrossRef] [PubMed]

3. Brammera, K.S.; Ohd, S.; Cobba, C.J.; Bjurstenb, L.M.; van der Heydec, H.; Jina, S. Improved bone-forming functionality on diameter-controlled $\mathrm{TiO}_{2}$ nanotube surface. Acta Biomater. 2009, 5, 3215-3223. [CrossRef]

4. Zhao, L.; Mei, S.; Chu, P.K.; Zhang, Y.; Wu, Z. The influence of hierarchical hybrid micro/nano-textured titanium surface wih titania nanotubes on osteoblast functions. Biomaterials 2010, 31, 5072-5082. [CrossRef] [PubMed]

5. Kokubo, T. Bioceramics and Their Clinical Applications; Woodhead Publishing: Cambridge, UK, 2008. 
6. Kawai, T.; Takemoto, M.; Fujibayashi, S.; Tanaka, M.; Akiyama, H.; Nakamura, T.; Matsuda, S. Comparison between alkali heat treatment and sprayed hsydroxyapatite coating on thermally-sprayed rough Ti surface in rabbit model: Effects on bone-bonding ability and osteoconductivity. J. Biomed. Mater. Res. Part B Appl. Biomater. 2015, 103, 1069-1081. [CrossRef]

7. Leeuwenburgh, S.C.G.; Wolke, J.G.C.; Jansen, J.A.; de Groot, K. Bioceramics and Their Clinical Applications; Kokubo, T., Ed.; Woodhead Publishing: Cambridge, UK, 2008; Chapter 20; pp. 464-484.

8. Strange, D.G.T.; Oyen, M.L. Biomimetic bone-like composites fabricated through an automated alternate soaking process. Acta Biomater. 2011, 7, 3586-3594. [CrossRef] [PubMed]

9. Nayab, S.N.; Jones, F.H.; Olsen, I. Modulation of the human bone cell cycle by calcium ion-implantation of titanium. Biomaterials 2007, 28, 38-44. [CrossRef] [PubMed]

10. Tsutsumi, Y.; Niinomi, M.; Nakai, M.; Tsutsumi, H.; Doi, H.; Nomura, N.; Hanawa, T. Micro-arc oxidation treatment to improve the hard-tissue compatibility of Ti-29Nb-13Ta-4.6Zr alloy. Appl. Surf. Sci. 2012, 262, 34-38. [CrossRef]

11. Park, J.W.; Park, K.B.; Suh, J.Y. Effects of calcium ion incorporation on bone healing of Ti6Al4V alloy implants in rabbit tibiae. Biomaterials 2007, 28, 3306-3313. [CrossRef] [PubMed]

12. Park, J.W.; Kim, Y.J.; Jang, J.H.; Kwon, T.G.; Bae, Y.C.; Suh, J.Y. Effects of phosphoric acid treatment of titanium surfaces on surface properties, osteoblast response and removal of torque forces. Acta Biomater. 2010, 6, 1661-1670. [CrossRef] [PubMed]

13. Takemoto, M.; Fujibayashi, S.; Neo, M.; Suzuki, J.; Matsushita, T.; Kokubo, T.; Nakamura, T. Osteoinductive porous titanium implants: Effect of sodium removal by dilute $\mathrm{HCl}$ treatment. Biomaterials 2006, 27, 2682-2691. [CrossRef] [PubMed]

14. Kawai, T.; Takemoto, M.; Fujibayashi, S.; Akiyama, H.; Yamaguchi, S.; Pattanayak, D.K.; Doi, K.; Matsushita, T.; Nakamura, T.; Kokubo, T.; et al. Osteoconduction of porous Ti metal enhanced by acid and heat treatments. J. Mater. Sci. Mater. Med. 2013, 24, 1707-1715. [CrossRef] [PubMed]

15. Kokubo, T.; Miyaji, F.; Kim, H.M.; Nakamura, T. Spontaneous formation of bonelike apatite layer on chemically treated titanium metals. J. Am. Ceram. Soc. 1996, 79, 1127-1129. [CrossRef]

16. Kokubo, T.; Yamaguchi, S. Novel bioactive materials developed by simulated body fluid evaluation: Surface-modified Ti metal and its alloys. Acta Biomater. 2016, 44, 16-30. [CrossRef] [PubMed]

17. So, K.; Kaneuji, A.; Matsumoto, T.; Matsuda, S.; Akiyama, H. Is the bone-bonding ability of a cementless total hip prosthesis enhanced by alkaline and heat treatments? Clin. Orthop. Relat. Res. 2013, 471, 3847-3855. [CrossRef] [PubMed]

18. Kizuki, T.; Matsushita, T.; Kokubo, T. Preparation of bioactive Ti metal surface enriched with calcium ions by chemical treatment. Acta Biomater. 2010, 6, 2836-2842. [CrossRef]

19. Yamaguchi, S.; Takadama, H.; Matsushita, T.; Nakamura, T.; Kokubo, T. Apatite-forming ability of $\mathrm{Ti}-15 \mathrm{Zr}-4 \mathrm{Nb}-4 \mathrm{Ta}$ alloy induced by calcium solution treatment. J. Mater. Sci. Mater. Med. 2010, 21, 439-444. [CrossRef]

20. Fukuda, A.; Takemoto, M.; Saito, T.; Fujibayashi, S.; Neo, M.; Yamaguchi, S.; Kizuki, T.; Matsushita, T.; Niinomi, M.; Kokubo, T.; et al. Bone bonding bioactivity of Ti metal and Ti-Zr-Nb-Ta alloys with Ca ions incorporated on their surfaces by simple chemical and heat treatments. Acta Biomater. 2011, 7, 1379-1386. [CrossRef]

21. Hamilton, H.; Jamieson, J. Deep infection in total hip arthroplasty. Can. J. Surg. 2008, 51, 111-117.

22. O'Neill, E.; Awale, G.; Daneshmandi, L.; Umerah, O.; Lo, K.W. The roles of ions on bone regeneration. Drug Discov. Today 2018, 23, 879-890. [CrossRef]

23. Barbara, A.; Delannoy, P.; Denis, B.G.; Marie, P.J. Normal matrix mineralization induced by strontium ranelate in MC3T3-E1 osteogenic cells. Metabolism 2004, 53, 532-537. [CrossRef] [PubMed]

24. Bonnelye, E.; Chabadel, A.; Saltel, F.; Jurdic, P. Dual effect of strontium ranelate: Stimulation of osteoblast differentiation and inhibition of osteoclast formation and resorption in vitro. Bone 2008, 42, 129-138. [CrossRef] [PubMed]

25. Jung, W.K.; Koo, H.C.; Kim, K.W.; Shin, S.; Kim, S.H.; Park, Y.H. Antibacterial activity and mechanism of action of the silver ion in staphylococcus aureus and Escherichia Coli. Appl. Envrion. Microbiol. 2008, 74, 2171-2178. [CrossRef] [PubMed]

26. Klasen, H.J. Historical review of the use of silver in the treatment of burns. Burns 2000, 26, 117-130. [CrossRef] 
27. Ferraris, S.; Venturello, A.; Miola, M.; Cochis, A.; Rimondini, L.; Spriano, S. Antibacterial and bioactive nanostructured titanium surfaces for bone integration. Appl. Surf. Sci. 2014, 311, 279-291. [CrossRef]

28. Kizuki, T.; Matsushita, T.; Kokubo, T. Antibacterial and bioactive calcium titanate layers formed on Ti metal and its alloys. J. Mater. Sci. Mater. Med. 2014, 25, 1737-1746. [CrossRef] [PubMed]

29. Yamaguchi, S.; Nath, S.; Matsushita, T.; Kokubo, T. Controlled release of strontium ions from a bioactive Ti metal with a Ca-enriched surface layer. Acta Biomater. 2014, 10, 2282-2289. [CrossRef] [PubMed]

30. Park, J.W.; Kim, Y.J.; Jang, J.H.; Suh, J.Y. Surface characteristics and primary bone marrow stromal cell response of a nanostructured strontium-containing oxide layer produced on a microrough titanium surface. J. Biomed. Mater. Res. A 2012, 100, 477-487. [CrossRef] [PubMed]

31. Chernozema, R.V.; Surmeneva, M.A.; Krauseb, B.; Baumbach, T.; Ignatov, V.P.; Prymak, O.; Loza, K.; Epple, M.; Ennen-Roth, F.; Wittmar, A.; et al. Functionalization of titania nanotubes with electrophoretically deposited silver and calcium phosphate nanoparticles: Structure, composition and antibacterial assay. Mater. Sci. Eng. C 2019, 97, 420-430. [CrossRef]

32. Surmeneva, M.A.; Sharonova, A.A.; Chernousova, S.; Prymak, O.; Loza, K.; Tkachev, M.S.; Shulepov, I.A.; Epple, M.; Surmenev, M.A. Incorporation of silver nanoparticles into magnetron-sputtered calcium phosphate layers on titanium as an antibacterial coating. Colloids Surf. B Biointerfaces 2017, 156, 104-113. [CrossRef]

33. Kokubo, T.; Takadama, H. How useful is SBF in predicting in vivo bone bioactivity? Biomaterials 2006, 27, 2907-2915. [CrossRef] [PubMed]

34. ISO22196:2011 Measurement of Antibacterial Activity on Plastics and Other Non-Porous Surfaces; ISO: Geneva, Switzerland, 2011.

35. Kolwn'ko, Y.V.; Kovnir, K.A.; Gavrilov, A.I.; Garshev, A.V.; Frantti, J.; Lebedev, O.I.; Churagulov, B.R.; Tendeloo, G.V.; Yoshimura, M. Hydrothermal synthesis and characterization of nanorods of various titanates and titanium dioxide. J. Phys. Chem. B 2006, 110, 4030-4038. [CrossRef]

36. NIST X-ray Photoelectron Spectroscopy Database, version 4.1; NIST: Gaithersburg, MA, USA, 2012.

37. Powder Diffraction Data File 00-004-0783. Joint Committee on Powder Diffraction Standards (JCPDS); International Centre for Diffraction Data: Newtown Square, PA USA, 2015.

38. Kokubo, T.; Yamaguchi, S. Novel bioactive titanate layers formed on Ti metal and its alloy by chemical treatments. Materials 2010, 3, 48-63. [CrossRef]

39. Yamaguchi, S.; Matsushita, T.; Nakamura, T.; Kokubo, T. Bioactive Ti metal with Ca-enriched surface layer able to release Zn ion. Key Eng. Mater. 2013, 529, 547-552. [CrossRef]

40. Yamaguchi, S.; Nath, S.; Sugawara, Y.; Divakarla, K.; Das, T.; Manos, J.; Chrzanowski, W.; Matsushita, T.; Kokubo, T. Two-in-one biointerfaces-Antimicrobial and bioactive nanoporous gallium titanate layers for titanium implants. Nanomaterials 2017, 7, 229. [CrossRef] [PubMed]

41. Yamaguchi, S.; Matsushita, T.; Kokubo, T. A bioactive Ti metal with a Ca enriched surface layer releases $\mathrm{Mg}$ ions. RSC Adv. 2013, 3, 11274-11282. [CrossRef]

42. Song, X.; Tang, W.; Gregurec, D.; Yate, L.; Moya, S.E.; Wang, G. Layered titanates with fibrous nanotopographic features as reservoir for bioactive ions to enhance osteogenesis. Appl. Surf. Sci. 2018, 436, 653-661. [CrossRef]

43. Inoue, Y.; Uota, M.; Torikai, T.; Watari, T.; Noda, I.; Hotokebuchi, T.; Yada, M. Antibacterial properties of nanostructured silver titanate thin films formed on a titanium plate. J. Biomed. Mater. Res. 2010, 92, 1171-1180. [CrossRef] [PubMed]

44. Prabu, V.; Karthick, P.; Rajendran, A.; Natarajan, D.; Kiran, M.S.; Pattanayak, D.K. Bioactive Ti alloy with hydrophilicity, antibacterial activity and cytocompatibility. RSC Adv. 2015, 5, 50767-50777. [CrossRef]

45. Okuzu, Y.; Fujibayashi, S.; Yamaguchi, S.; Yamamoto, K.; Shimizu, T.; Sono, T.; Goto, T.; Ohtsuki, B.; Matsushita, T.; Kokubo, T.; et al. Strontium and magnesium ions released from bioactive titanium metal promote early bone bonding in a rabbit implant model. Acta Biomater. 2017, 63, 383-392. [CrossRef] [PubMed]

46. Spriano, S.; Yamaguchi, S.; Baino, F.; Ferraris, S. A critical review of multifunctional titanium surfaces: New frontiers for improving osseointegration and host response, avoiding bacteria contamination. Acta Biomaterialia 2018, 79, 1-22. [CrossRef] [PubMed]

47. Fujibayashi, S.; Neo, M.; Kim, H.-M.; Kokubo, T.; Nakamura, T. A comparative study between in vivo bone ingrowth and in vitro apatite formation on $\mathrm{Na}_{2} \mathrm{O}-\mathrm{CaO}-\mathrm{SiO}_{2}$ glasses. Biomaterials 2003, 24, 1349-1356. [CrossRef] 
48. Takemoto, M.; Nakamura, T. Bioceramics and Their Clinical Applications; Kokubo, T., Ed.; Woodhead Publishing: Cambridge, UK, 2008; Chapter 8; pp. 183-198.

49. Sila-Asna, M.; Bunyaratvej, A.; Maeda, S.; Kitaguchi, H.; Bunyaratavej, N. Osteoblast differentiation and bone formation gene expression in strontium-inducing bone marrow mesenchymal stem cell. Kobe J. Med. Sci. 2007, 53, 25-35. [PubMed] 